\title{
THE EVALUATION OF LAND AREA MEASUREMENT USING GPS TECHNOLOGY
}

\author{
${ }^{a}$ Vikky Aprelia Windarni, ${ }^{\mathbf{b}}$ Eko Sediyono, ${ }^{\mathrm{c}}$ Adi Setiawan \\ a,b Magister of Information System, Universitas Kristen Satya Wacana \\ ${ }^{c}$ Faculty of Science and Mathematics, Universitas Kristen Satya Wacana \\ Jl. Diponegoro 52-60 Salatiga, 50711- Indonesia \\ E-mail: vikkyaprelia@gmail.com
}

\begin{abstract}
The use of GPS is now widely used by various parties, especially in determining the position of object location. GPS can be used to measure the land areas, on both wide and flat areas. It can also be used both at night and day, and even it can be used in bad weather conditions. This paper discusses the evaluation of the measurement result of land area using GPS technology compare to the information containing on the land certificate document. The generated GPS coordinates will be converted into units of meter so that length of each side can be known. Heron formula is used to calculate the area of a land plotted on the Google Map. From the series of measurement, GPS measurement fall above the land area expressed in the certificate and bellow the meter tape measurement. This measurement still need to study further to get a stable measurement. But it can be used by public community to show the land location to facilitate the land trading. The limitation that must be considered in using GPS is that GPS signal should not be hindered by any barriers such as leafy trees or tall buildings.
\end{abstract}

Keywords: National Land Agency (BPN), Heron formula, Global Positioning System (GPS), Google Maps API. 


\section{INTRODUCTION}

Land mapping in Indonesia is conducted by the Office of National Land Agency (BPN). In general measuring the land are closely related with consideration to give certainty and laws protection against subject and object of land rights. There are two methods in measuring the land area used by BPN, they are terrestrical and photogrametrical.

Terrestrical method is direct measurement on the field by means of taking angular and/or distance data, which done by trilateration (distances), triangulation (angles) or triangulateration (angles and distances) data collection. Instruments that be used are theodolite and meetband or Electronic Distance Measuring (EDM) device and data recorder. While fotogrametris method is measurement using a means of aerial photos based on satelite image. Hasil pengukuran di lokasi ditandai dengan menggunakan patok semen [1].

All of the measurements conduct under the act, one of them is Regulation of the Minister of agrarian and Spatial Planning (Peraturan Menteri Agraria dan Tata Ruang/Kepala Badan Pertanahan Nasional) No. 35 year 2016 about the acceleration of the implementation of a Complete Systematic Land Registration. It is intended to meet the principle of delimitation of contradicture and the principle of publicity.

Meanwhile the mapping technology is thriving with the presence of GoogleMap completed with GoogleAPI to ease its use. Unfortunately this technology can not be used by BPN, because there is no law regulating their use. This paper is intended to evaluate the measurement and the determination of the boundaries of land based on GoogleMap and GoogeAPI with the reference methods of measurement for official use by the BPN.

Chekole, performed a research which examines a Comparative Study: Surveying Using GPS, Total Station and Terrestrial Laser Scanner. The study was aimed to compare the level of accuracy, precision and required time. The results of this study showed that there was no error in the measurement using of GPS for it was precise and accurate, and the use of Total Station had been proven required more time [2].

Shunfu $\mathrm{Hu}$ and Tiang Dai conducted a research that examined the development of the online map application using Google Maps
API, SQL Database and ASP.NET. The study showed an online mapping application that was successfully developed and it also provided an advanced functionality for searching, filtering and performing an interface tab that offers users the ability to manipulate data. The case study that is presented in this article provides an advanced functionality to display a number of locations and thousands of USDA-based plantations (United States Department of Agriculture) on the internet with icons and legends of customized maps [3].

A. Omar Ibrahim and K.J Mohsen conducted a research that examined the Design and Implementation of Location Online Services Using of Google Maps for Android Mobile. Results of this study shows an online mapping application using of Google Maps API, Google Direction APIs, JSON, MySQL database and PHP. This application is a type of open source application with high reliability. This application helps tourists or users to add a place on a map or it is able to remove the place from the map or review information about any place on the map, and to calculate the route, duration and distance between points and places on the map [4].

Windarni A.V, et al conducted a research that investigated the use of GPS and Google Maps for Digital Mapping of Land Certificate. The study concludes that digital design of a land certificate is superior to online maps owned by BPN. People who use this application will get information about a map in accordance with the information contained in the land documents and it will simplify the search of land location [5].

I. O. Bildirici and N.N. Ulugtekin performed a research on the Web Mapping using of Google Maps Mashup: Overlaying Geodata, which they studied the map mashups that were created using of API mapping. In the study, they introduced the basics for creating of map mashups. Map Mashups can be used to indicate the location of businesses, hotels, convention centers, etc. [6].

GPS (Global Positioning System) is a global navigation system that is used to determine the location, speed, direction and time. This system is designed to provide information about a position and it is suitable for all kinds of weather, designed to give precise three- 
dimensional position and speed, to give continuous information about the time all over the world [7]. In Indonesia, GPS is widely used by various parties. If we want to know position of an object, we need a GPS receiver that has function to receive GPS signals, and that position is transformed into points that known as waypoint. The waypoints are latitude and longitude coordinate points of an object position.

Google Maps API is a service provided by Google for users of Google Map to be used in developing of apps. Google Maps API provides several features for map manipulation and adds contents through various types of services that are owned by Google, and it allows users to build enterprise applications on its website.

Heron formula is a formula that is used to find the area of a triangle by the length of its three sides. This formula has two versions of which the first version is Heron formula in Euclid geometry or plane geometry and the second version is Heron formula in spherical geometry or geometry in the area of a ball [8].

\section{DYNAMIC SYSTEM}

The method used in this research is Research and Development approach using of dynamic system, which is to know how the extent of achievement with the usage of GPS to calculate the area of a land plot and the usage of Google maps for mapping of a land certificate. The Research and Development ( $R$ \& D) approach is a research method that is useful for the analysis of specific needs and to test the effectiveness of products that can be beneficial for society in general. The measures of Research and Development (R \& D) are as follows:

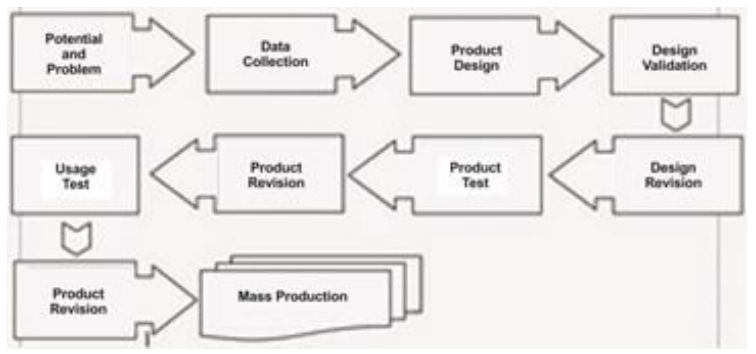

Figure 1. The Measures of Research \& Development (R\&D) Method Usage [9]

\section{Potential of Problems}

Potential of problems in this research is how to calculate the result of a land plot area quickly and to analyze the results of comparison of land plot areas, as well as to get information accurately. Allegedly, a quick result is obtained through the help of GPS technology in calculating the area of a wide and flat land plot. This accurate information can also be provided through the help of GPS technology and through the manipulation mapping of Google Maps API. By this method, hopefully, people will be able to use the digital format of land mapping, to get clear information about the history of changes related to the rightful land holder and to get information about the land borders in the form of its surrounding coordinate points.

\section{Data Collection}

Data collection in this study was carried out by utilizing of Garmin series-Oregon ${ }^{\circledR} 650$ GPS, to determine the coordinate points (latitude and longitude) of land borders owned by the land owner. It needs 10 land plots in collecting data by taking one coordinate of land borders in one day and carried over 10 days. All studied land plots have various land forms, and as a result, they have a various number of land border points.

\section{Product Design}

Product design or the application of mapping of land certificate can be used by two types of users who each of them will have different access rights within the application. One of users performs the login process is as admin user and the second user as ordinary user.

\section{Design Validation}

Design validation is the stage to evaluate the product design or the generated application, which is tailored to the needs of the National Land Agency (BPN).

\section{Design Revision}

The design revision can be done if users or experts has found out the weaknesses of the generated product or application. If there are still weaknesses in the product or application, it is necessary to revise the design.

\section{Product Test}

Product test of a land certificate mapping application was done to the land plots that had 
a valid certificate, with a total of 10 land locations.

\section{Product Revision}

Product revision was made after the phase of product test. By studying the weaknesses of the generated product or application, the researchers performed the revision phase of the product or application.

\section{Usage Test}

Usage test was carried out at 10 land locations that already have certificates, with an application design that had been planned and data that had been ready for the test.

\section{Product Revision}

Product revision will be done again if there are weaknesses in the generated product or application.

\section{Mass Production}

Mass production can be done if the product or application that was created has passed the test and can be applied to real conditions and it has results worthy to be developed.

\section{RESULT AND DISCUSSION}

UML (Unified Modeling Language) is a visual modeling method for object-oriented system design and as a standardized language in visualization, design and documentation of a software system [10]. Design of this study uses UML to create the design draft of land certificate mapping. Meanwhile, the implemented UML diagrams are context diagram and sequence diagram. The purpose of this design is that users can understand the system design that will be built.

Figure 2 is context diagram of mapping system of land certificates. There are two entities, i.e:

1) National Land Agency (admin)

a) Input from the system in the form of coordinate points of land, land ownership data input and the input scan file of land certificates.

b) Output to the system in form of the success storage of coordinate land data and land ownership data which are stored in the database of land certificate information based on certificate number owned by the land owners. a) Input to the system in form of the certificate number owned by the land owners.

b) Output from system in form of information about land certificates and mapping that are stored digitally.

For the result of user sequence diagram, it can be seen in Figure 3, which there is one actor (user) and 9 objects (login, DAO user, user database, home, view certificates, view certificates DAO, certificates database, map the certificates and exit).

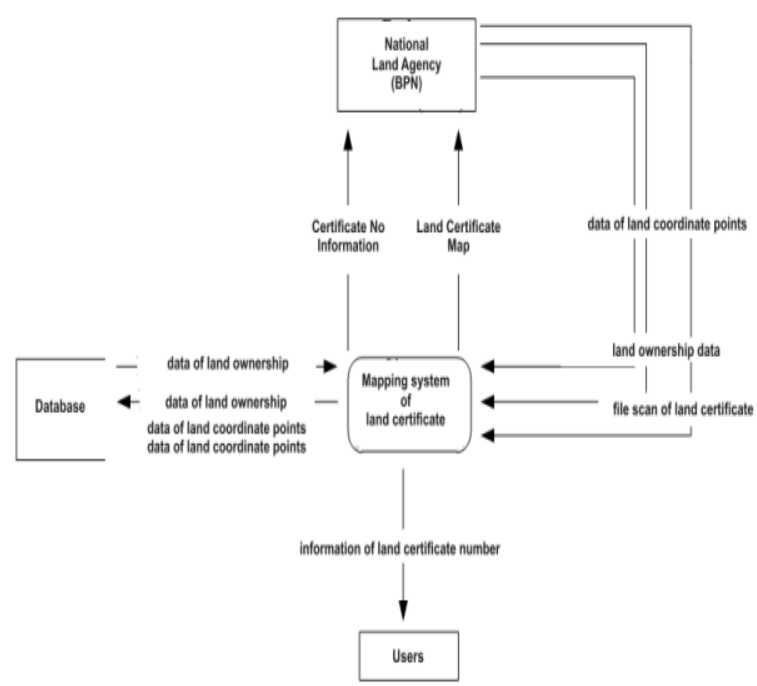

Figure 2. Context Diagram of the System

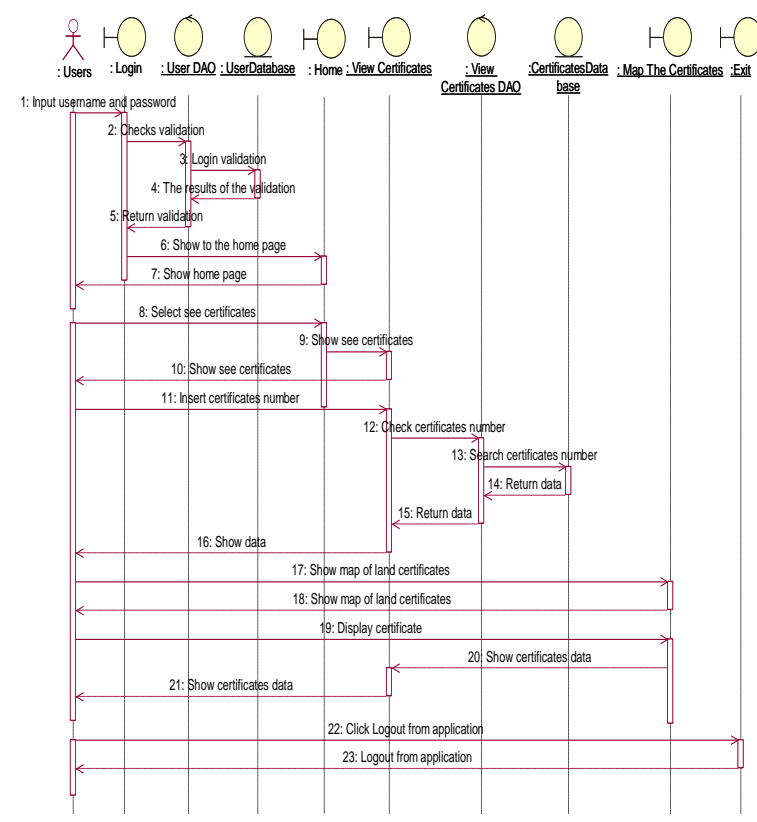

Figure 3. Sequence Diagram User

2) User 


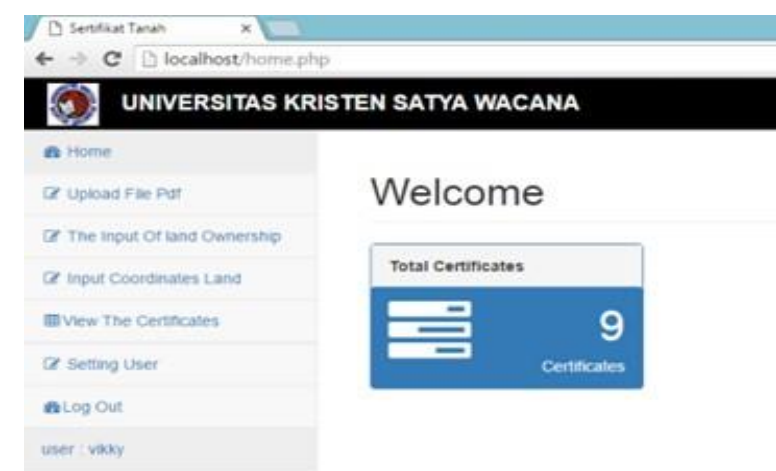

Figure 4. The Display of The Front Page After The Admin Logging In

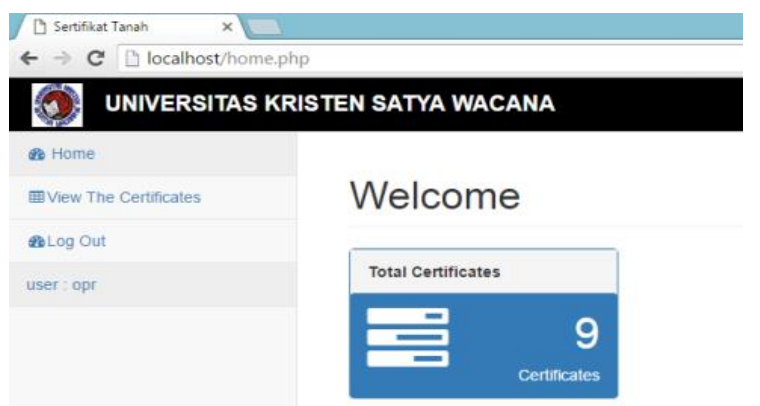

Figure 5. The Display of The Front Page After The User Logging In

\section{INFORMATION}

No of Certidicate: 563

Name of the Owner: Ari Setyo Palupi

Village: Ngentak

Sub district: Tengaran

District: Semarang

Province: Central Jave

Land Area: $540 \mathrm{~m} 2$

Notes:

The First Rightful Land Holder: Ari Setyo Palup

Land Area According to GPS: $498,85 \mathrm{~m}^{2}$

Land Area According to Meter Tape: $480,92 \mathrm{~m}^{2}$

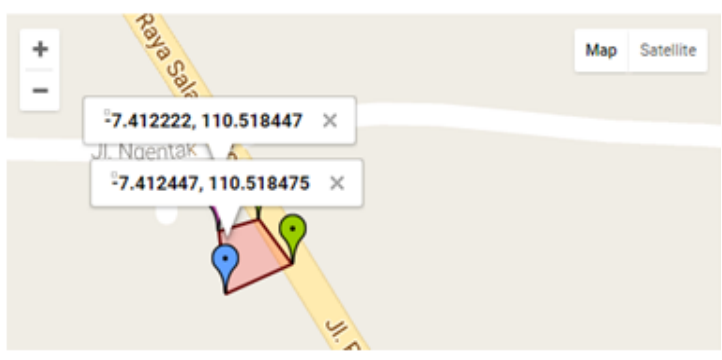

Figure 6. The Result of Digital Mapping After Process Inputs the coordinate points

Figure 4 is the front page after the admin performs $\log$ in on the application and Figure 5 is the front page after user performs $\log$ in. It can be seen that both user and admin user have different access rights in the mapping application.
Figure 6 is the result of digital mapping after the admin inputs the coordinate points. The determination of coordinate points is adjusted with location of land borders owned by the land owner in accordance with actual conditions in the field. When the admin or user is clicking on each corner of the map, he/she will get different information about the value of coordinate points at each corner of the land borders and he/she will get the same information about certificate number, owner's name, land location, the wide of the land, the history records of the rightfully land owner. Once confirmed, a survey conducted at 10 locations of the land plot that already have a certificate document, with data collection for 10 days. The land borders in form of coordinate points (latitude and longitude) will then converted into units of meters, so that the length of each side can be known. Before starting the calculation of the distance among corners, please note that the circumference of the earth at the equator is $40075.017 \mathrm{~km}$ [11]. Researchers use a calculation to find out the distance between two points on the earth's surface with the assumption that the earth is elliptic, of which they can use the formula as seen in Equation (1):

$d=D\left(1+\left(f H_{1} \sin ^{2} F \cos ^{2} G-f H_{2} \cos ^{2} F \cos ^{2} G\right)\right)(1)$

where

$f=\frac{1}{298,257} ; a=6378140 ; b=6356755$

$F=\frac{y_{2}+y_{1}}{2} ; G=\frac{y_{2}-y_{1}}{2} ; \lambda=\frac{x_{2}+x_{1}}{2}$

$S=\sin ^{2} G \cos ^{2} \lambda+\cos ^{2} F \sin ^{2} \lambda$,

$C=\cos ^{2} G \cos ^{2} \lambda+\sin ^{2} F \sin ^{2} \lambda$,

$\tan \omega=\sqrt{\frac{s}{c}} ; R=\frac{\sqrt{S C}}{\omega} ; D=2 \omega a$

and $\omega$ is changed into radian

$H_{1}=\frac{3 R-1}{2 C} ; H_{2}=\frac{3 R+1}{2 S}$,

with:

$a$ : the earth trellis on equator,

$b$ : the earth trellis on poles,

$f$ : relative error (mean) [12].

Heron formula is the formula used to calculate the area of a triangle whose sides are known, 
because the shape of the area of a land is always irregular, this formula can be used to find the results of land areas. In determining the land area, the authors use the Heron Euclid formula (Heron formula for a horizontal plane), then it will be obtained by the formula:

$\Delta=\sqrt{s(s-a)(s-b)(s-c)}$

with:

$s=\frac{1}{2}(a+b+c)[13]$

Table 1. Result of Information About Land Areas On Certificate Documents, Calculation Using GPS and Calculation Using a Meter Tape

\begin{tabular}{cccc}
\hline $\begin{array}{c}\text { Certificate } \\
\text { Number }\end{array}$ & $\begin{array}{c}\text { Land Area } \\
(\text { Certificate }) \\
\left(\mathrm{m}^{2}\right)\end{array}$ & $\begin{array}{c}\text { Land Area } \\
(\mathrm{GPS}) \\
\left(\mathrm{m}^{2}\right)\end{array}$ & $\begin{array}{c}\text { Land Area } \\
(\text { Meter } \\
\text { Tape })\left(\mathrm{m}^{2}\right)\end{array}$ \\
\hline 628 & 748 & 824.61 & 825.15 \\
647 & 1446 & 1552.12 & 1488.60 \\
781 & 1127 & 1165.88 & 1166.38 \\
494 & 446 & 478.07 & 468.13 \\
622 & 2289 & 2529.79 & 2428.36 \\
563 & 540 & 491.68 & 480.92 \\
627 & 229 & 226.04 & 225.8 \\
623 & 692 & 745.06 & 753.1 \\
113 & 4640 & 4582.72 & 4637.42 \\
263 & 110 & 110.26 & 109.10 \\
\hline
\end{tabular}

Table 2. Calculation Result to Find Out The Range of Confidence Interval Using GPS Technology

\begin{tabular}{cccc}
\hline $\begin{array}{c}\text { Certificate } \\
\text { Number }\end{array}$ & $\begin{array}{c}\text { Land Area } \\
(\mathrm{GPS})\left(\mathrm{m}^{2}\right)\end{array}$ & $\begin{array}{c}\text { Upper } \\
\text { Limit }\left(\mathrm{m}^{2}\right)\end{array}$ & $\begin{array}{c}\text { Lower } \\
\text { Limit }\left(\mathrm{m}^{2}\right)\end{array}$ \\
\hline 628 & 824.61 & 807.71 & 841.51 \\
647 & 1552.12 & 1498.92 & 1605.32 \\
781 & 1165.88 & 1122.30 & 1209.46 \\
494 & 468.13 & 425.72 & 510.54 \\
622 & 2529.79 & 2432.83 & 2626.75 \\
563 & 491.68 & 460.63 & 522.73 \\
627 & 226.04 & 218.57 & 233.50 \\
623 & 745.06 & 682.79 & 807.34 \\
113 & 4582.72 & 4478.15 & 4687.28 \\
263 & 110.26 & 110.21 & 115.09 \\
\hline
\end{tabular}

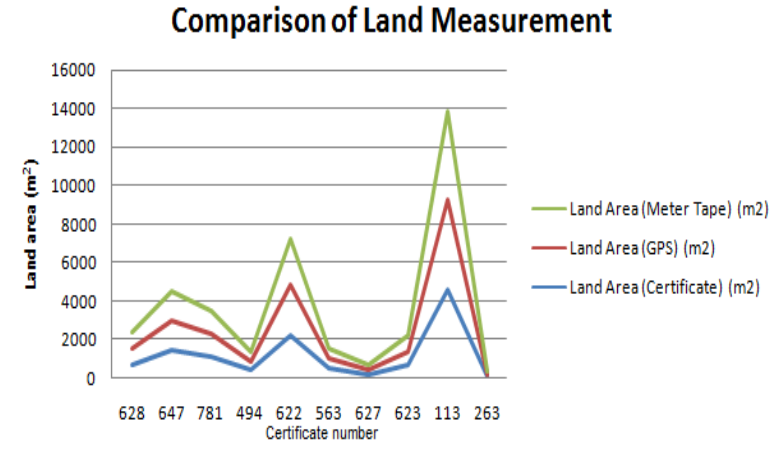

Figure 7. Comparison of land Measurement

Table 1 show the calculation of the land areas according to the certificate document, the result of land areas according to the GPS calculation and the measurement using a meter tape. In collecting the data, researchers used 10 land sites with different shape. Most of them have a relatively flat contour. From the calculation and measurement, we concluded that the information about the land areas on certificate documents and the calculation of land areas by utilizing GPS technology showed different results. After getting the results of land areas using GPS, the range for the sample mean value or confidence interval value can be found. We use a confidence level $95 \%$, which means that we believe sample mean $95 \%$ exists within the obtained interval. The obtained data show different results (information about land areas on the certificate documents and calculations are made using of GPS and using of meter tape). The land area measurement using of a tape meter can be used as additional information on the digital recording of land certificate mapping.

Table 2 is the result of the calculation to determine the range of confidence interval using of GPS Technology. We use of 10 times measurement for one location of land plot and conducted over 10 days. In this study, we use a sample size less than 30 to determine the formula for calculating upper limit and lower limit of the range and estimation of population interval mean can be seen in Equation (3) [14].

$\bar{Y}-t_{\frac{\alpha}{2}, v} \frac{s}{\sqrt{n}}<\mu<\bar{Y}+t_{\frac{\alpha}{2}, v} \frac{s}{\sqrt{n}}$

There are differences in the measurement results between the information about land areas on the certificate documents and the calculation of land areas using of GPS technology. From the series of measurement, 
GPS measurement fall above the land area expressed in the certificate and bellow the meter tape measurement. It can be seen in the Figure 7. This measurement still need to study further to get a stable measurement. The limitation that must be considered in using GPS is that GPS signal should not be hindered by any barriers such as leafy trees or tall buildings. The use of GPS is actually very interesting because GPS can be used to calculate the result of a land area in a large and flat area and GPS can be used day or night and even in adverse weather conditions.

Besides, GPS can be used with free of charge; to find out relative position of coordinates using of GPS receiver is very much easy and it does not need a lot of effort. Finally, the use of GPS in determining a relative position is not affected by the topographical condition that is under survey area, compared to the use of terrestrial methods such as polygon measurement [7].

The advantage of this mapping, among others, BPN and public in general will have a land mapping that is made digitally. Besides, it helps the users in trading the land. It helps displaying the information contained in the map (the name of the land owner, the address of the land site, it displays the comparison of land area result on the certificate document while measured using a tape meter and the result obtained using of GPS technology and other records). It also facilitates the search for the location of a land when there are no land boundaries (such as tree or benchmark created by the BPN) by which the coordinate points (latitude and longitude) can be used as a border benchmark. Finally, it helps in facilitating storage. Digital-made land mapping on certificate look more flexible, but it still need to study further more to get more stable measurement. It can be used by public community to show the land location to facilitate the land trading. On the website owned by the BPN (http://peta.bpn.go.id/) [15], there is online map that plots any certificate on its corresponding places on the map, but there are not any information about the land owners and it shows only relative distribution of land areas.

\section{CONCLUSION}

Based on the research that has been done, it can be concluded that there are different information results between the measurement of land areas contained on the certificate documents and the measurement of land areas using GPS technology. From the series of measurement, GPS measurement fall above the land area expressed in the certificate and bellow the meter tape measurement. This measurement still need to study further to get a stable measurement. But it can be used by public community to show the land location to facilitate the land trading. The limitation that must be considered in using GPS is that GPS signal should not be hindered by any barriers such as leafy trees or tall buildings.

\section{ACKNOWLEDGMENTS}

The authors would like to express our special thanks of gratitude to the Director General of Higher Education on funding provided through a research grant of Post Graduate Team of 2016 budget year.

[3] S. Hu and T. Dai, "Online Map Application Development Using Google Maps API, SQL Database, and ASP .NET," Int. J. Inf. Commun. Technol. Res., vol. 3, no. 3, 2013.

[4] O. A. Ibrahim and K. J. Mohsen, "Design and implementation an online location based services using Google maps for android mobile," 
Int. J. Comput. Netw. Commun. Secur. CNCS, vol. 2, no. 3, pp. 113 118, 2014.

[5] V. A. Windarni, E. Sediyono, and A. Setiawan, "Using GPS and Google maps for mapping digital land certificates," in Informatics and Computing (ICIC), International Conference on, 2016, pp. 422-426.

[6] I. O. Bildirici and N. N. Ulugtekin, "Web mapping with Google maps mashups: overlaying geodata," in $A$ special joint symposium of ISPRS technical commission IV \& AutoCarto in conjunction with ASPRS/CaGIS 2010 fall specialty conference, Orlando, FL, 2010, pp. 15-19.

[7] H. Z. Abidin, "Penentuan Posisi dengan GPS dan aplikasinya," Jkt. PT Pradnya Paramita, 2007.

[8] A. Baragar, A Survey of Classical and Modern Geometries: With Computer Activities. Prentice Hall, 2001.
[9] Sugiyono, Metode Penelitian Kuantitatif, Kualitatif Dan $R \& D$. Bandung: Alfabeta, 2008.

[10] J. Rumbaugh, I. Jacobson, and G. Booch, Unified modeling language reference manual, the. Pearson Higher Education, 2004.

[11]National Geospatial - Intelligence Agency, "World Geodetic System (WGS-84)." [Online]. Available: http://earthinfo.nga.mil/gandg/wgs84/.

[12] Jean Meeus, Astronomical Algorithm. USA: Williman-Bell, 1998.

[13] Dubham W., Heron's Formula for Triangular Area. New York: Wiley, 1990.

[14] C. L. Chiang, Statistical methods of analysis. World Scientific, 2003.

[15] Badan Pertahanan Nasional, "Peta Online." [Online]. Available: http://peta.bpn.go.id/. 